\title{
Pengembangan Sistem Informasi Penerimaan dan Pengeluaran Kas Berbasis WEB (Studi Kasus Pada SMP Widya Sakti)
}

\author{
Ni Kadek Meita Dwita Sari ${ }^{1)}$, Ni Made Estiyanti ${ }^{2)}$, AA Ayu Putri Ardyanti ${ }^{3)}$ \\ ${ }^{122)}$ Program Studi Sistem Informasi Akuntansi, STMIK Primakara \\ ${ }^{3)}$ Program Studi Teknik Informatika, STMIK Primakara \\ Jalan Tukad Badung No.135 Renon, Denpasar, Bali Telp.(0361) 8956085

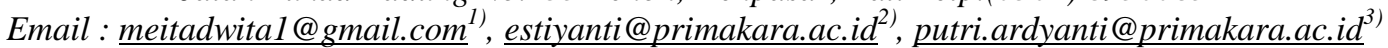

\begin{abstract}
Perkembangan teknologi pada era globalisasi ini menjadikan teknologi sebagai pilar penting dalam membantu kegiatan oprasional suatu organisasi atau instansi guna untuk mencapai tujuan yang diingikan oleh instansi. Perkembangan teknologi informasi merupakan salah satu bagian penting yang dapat membantu seseorang dalam mengolah berbagai data menjadi sebuah informasi yang dapat berguna bagi orang yang memerlukannya. SMP Widya Sakti merupakan sebuah instansi yang yang sudah berdiri sejak 24 maret 1978 sampai saat ini. Dimana pada instansi ini sudah menggunakan teknologi sebagai pembantu pengolahan data keuangan dan dapat menghasilkan suatu laporan yang selalu dilaporkan setiap bulan. Tujuan penelitian ini adalah untuk merancang sistem informasi penerimaan dan pengeluaran kas berbasis Web. Pendekatan yang digunakan dalam penelitian ini adalah pendekatan kualitatif. Metode dalam pengembangan aplikasi ini menggunakan Metode Waterfall. Pengembangan Sistem Informasi Penerimaan dan Pengeluaran Kas dirancang menggunakan database MySQL dan bahasa Pemograman Hypertext Preprocessor (PHP) sedangkan untuk pengujian sistem menggunakan black box testing.Aliran data dan rancangan sistem menggunakan Data Flow Diagram ( DFD) sedangkan perancangan table pada basis data menggunakan Entity Realationship Diagram (ERD) dengan adannya pengembangan sistem penerimaan dan pengeluaran kas berbasis Web ini diharapkan dapat membantu mengembangkan teknologi informasi yang dulunya masih dilakukan secara komputerisasi dan sekarang di kembangkan dalam sebuah program. Selain itu dengan adanya sistem ini, perasalahan dalam pembuatan laporan keuangan dapat di atasi dengan mudah Pada SMP Widya Sakti.
\end{abstract}

Keywords: Revenue and Expense Information System

\begin{abstract}
Abstrak
The development of technology in this era of globalization makes technology an important pillar in helping operational activities of an organization or agency in order to achieve the desired goals of the agency. The development of information technology is one important part that can help a person in processing various data into an information that can be useful for people who need it. Widya Sakti Middle School is an institution that has been established since 24 March 1978 until now. Where in this agency has used technology as a financial data processing assistant and can produce a report that is always reported every month. The purpose of this research is to design a Web-based cash receipt and expenditure information system. The approach used in this study is a qualitative approach. The method in developing this application uses the Waterfall Method. Development of Cash Revenue and Expenditure Information System is designed using MySQL database and Hypertext Preprocessor Programming (PHP) while for system testing uses black box testing. Data flow and system design uses Data Flow Diagrams (DFD) while the table design in the database uses Entity Realationship Diagrams (ERD) with the development of Web-based cash receipts and disbursements systems is expected to help develop information technology that was previously still being computerized and is now being developed in a program. In addition, with this system, problems in making financial reports can be easily overcome in Widya Sakti Middle School.
\end{abstract}

Kata kunci : Sistem Informasi Penerimaan dan Pengeluaran 


\section{Pendahuluan}

Perkembangan teknologi pada era globalisasi ini menjadikan teknologi sebagai pilar penting dalam membantu kegiatan oprasional suatu organisasi atau instansi guna untuk mencapai tujuan yang diingikan oleh instansi. Perkembangan teknologi informasi merupakan salah satu bagian penting yang dapat membantu seseorang dalam mengolah berbagai data menjadi sebuah informasi yang dapat berguna bagi orang yang memerlukannya.

Salah satu peran penting teknologi informasi di lingkungan sekolah adalah untuk mempermudah pencatatan penerimaan dan pengeluaran dana kas. Tetapi tidak semua sekolah memanfaatkan teknologi informasi dengan baik, maka dari itu tidak sedikit sekolah yang masih melakukan pekerjaan dengan cara konversional. Sekolah seharusnya sudah mulai menerapkan teknologi informasi yang efektif dan efisien. Hal ini dilakukan agar mampu meningkatkan akuntabilitas dan transparansi pencatatan keuangan sekolah dan meminimalkan kesalahan dalam pencatatan keuangan.

Pada Penelitian terdahulu menurut Jamaludin Malik pada penelitiannya yang berjudul Sistem Informasi Pengolahan dan Laporan Keuangan Dana BOS Berbasis Multi User di MTs Sudirman Jimbaran. Sistem informasi ini dibangun dengan menggunakan bahasa pemrograman Visual Basic (VB) dan database MySQL. Aliran data dan perancangan sistem ini menggunakan Data Flow Diagram (DFD), sedangkan perancangan tabel pada basis data menggunakan Entity Realationship Diagram (ERD). Metode pengembangan yang digunakan adalah metode System Development Life Cycle (SDLC) dengan model waterfall. Dengan adanya sistem informasi ini dapat membantu dalam mempermudah pengelolaan dana Bantuan Operasional Sekolah (BOS) di Sekolah Dasar Negeri Sekayu. Sehingga laporan keuangan yang dihasilkan memiliki data yang akurat dan lengkap serta menjadi tepat waktu[1].

SMP Widya Sakti merupakan sekolah yang masih melakukan pencatatan secara manual. Secara garis besar sumber pendapatan SMP Widya sakti bersumber pembayaran Sumbangan Pembinaan dan Pendidikan (SPP). SPP adalah sejumlah biaya yang dibebankan kepada siswa untuk membantu lembaga pendidikan, dan memperlancar proses belajar mengajar. Penerimaaan dana tersebut akan diolah oleh sekolah untuk memperlancar proses belajar mengajar. Karena banyaknya penerimaan dan pengeluaran yang harus dicatat oleh bendahara, untuk mengantisipasi kehilangan data yang sering di alami, maka dari itu dengan adanya teknologi informasi dapat mempermudah pekerjaan bagian Tata Usaha (TU) khususnya pada bagian bendahara.

Sistem pencatatan penerimaan dan pengeluaran dana kas yang bersifat konvensional ini mengakibatkan banyaknya memakan waktu dalam proses pencatatan, pembayaran Sumbangan Pembinaan dan Pendidikan (SPP) dan juga lamanya dalam pembuatan laporan keuangan dengan menggunakan website, user dengan mudah dapat mengakses data dari mana saja dan kapan saja user inginkan. Sistem pencatatan penerimaan dan pengeluaran dana kas yang bersifat konvensional ini mengakibatkan banyaknya memakan waktu dalam proses pencatatan, pembayaran Sumbangan Pembinaan dan Pendidikan (SPP) dan juga lamanya dalam pembuatan laporan keuangan. Karena ketika siswa melakukan pembayaran Sumbangan Pembinaan dan Pendidikan (SPP), petugas Tata Usaha (TU) harus mencari nama siswa tersebut dalam sebuah buku pemungutan bulanan. Setelah itu baru petugas Tata Usaha melakukan pencatatan kedalam buku harian tersebut dan juga melakukan pencatatan ke dalam kartu pembayaran Sumbangan Pembinaan dan Pendidikan (SPP). Sama halnya dalam pembuatan laporan pembayaran Sumbangan Pembinaan dan Pendidikan (SPP), petugas Tata Usaha (TU) harus mendata atau mencari satu persatu nama-nama siswa yang telah melakukan pembayaran dan nama-nama siswa yang belum melakukan pembayaran. Dengan pembayaran yang masih konvensional mengakibatkan terjadinya kesalahan dalam pencatatan Sumbangan Pembinaan dan Pendidikan (SPP) kedalam buku pemungutan bulanan, begitu pula halnya dengan pencatatan pengeluaran kas. Bagian keuangan harus merekap satu persatu data pengeluaran, hal tersebut dapat menyita banyak waktu. Maka peran teknologi informasi disni sangat penting, untuk mengatasi masalah pencatatan keuangan yang di alami SMP Widya Sakti.

Berdasarkan permasalahan diatas peneliti bertujuan untuk membuat sebuah sistem yang berjudul "Pengembangan Sistem Informasi Penerimaan dan Pengeluaran Kas Berbasis Web pada SMP Widya Sakti”. Dimana dengan adanya sistem ini, bagian Tata Usaha (TU) khususnya bendahara dapat dengan mudah membuat laporan keuangan baik dalam penerimaan maupun pengeluaran kas sekolah. Selain itu dengan adanya sistem ini, bagian Tata Usaha (TU) dapat dengan mudah mengakses data keuangan sekolah.

\section{Pembahasan}

\section{A. Sistem}

Sistem adalah seperangkat bagian-bagian yang dikoordinasikan untuk melaksanakan seperangkat tujuan. Sehingga dapat disimpulkan bahawa sistem merupakan rangkaian bagian - bagian yang saling berhubungan dan saling berpengaruh satu sama lain yang dikoordinasikan untuk melaksanakan seperangkat tujuan tertentu [2].

\section{B. Informasi}

Informasi adalah data yang telah diolah menjadi bentuk yang lebih berarti dan berguna bagi penerimanya untuk mengambil keputusan masa kini maupun masa yang akan datang [3].

\section{Website}

Website merupakan terobosan baru sebagai teknologi sistem informasi yang menghubungkan data dari banyak sumber dan layanan yang beragam macamnya di 
internet, web cepat sekali populer di lingkungan pengguna internet, karena kemudahan yang diberikan kepada pengguna internet untuk melakukan penelusuran, penjelajahan, dan pencarian informasi [5]

\section{Sistem Akuntansi Penerimaan Kas}

Sistem akuntansi penerimaan kas adalah suatu catatan yang dibuat untuk melaksanakan kegiatan penerimaan uang dari penjualan tunai atau dari piutang yang siap dan bebas digunakan untuk kegiatan umum perusahaan. Suatu perusahaan membuat catatan yang siap digunakan untuk kegiatan umum penerimaan uang, baik berupa uang tunai maupun piutang [2]

\section{E. Sistem Akuntansi Pengeluaran Kas}

Sistem akuntansi pengeluaran kas adalah suatu catatan yang dibuat untuk melaksanakan kegiatan pengeluaran baik dengan cek maupun dengan uang tunai yang digunakan untuk kegiatan umum perusahaan. Sistem akuntansi pengeluaran kas adalah suatu proses, cara, perbuatan mengeluarkan alat pertukaran yang diterima untuk pelunasan utang dan dapat diterima sebagai suatu setoran ke bank dengan jumlah sebesar nominalnya, juga simpanan dalam bank atau tempat lainnya yang dapat diambil sewaktu-waktu [2].

\section{F. Database}

Sistem basis data adalah suatu sistem menyusun dan mengelola record-record menggunakan komputer untuk menyimpan atau merekam serta memelihara data operasional lengkap sebuah organisasi atau perusahaan sehingga mampu menyediakan informasi yang optimal yang diperlukan pemakai untuk proses mengambil keputusan [5].

\section{G. Data Flow Diagram (DFD)}

Data Flow Diagram (DFD) merupakan alat yang digunakan pada metodologi pengembangan sistem yang terstruktur (structured analysis and design) [9].

\section{H. Entity Relationship Diagram (ERD)}

Entity Relationship Diagram (ERD) digunakan untuk mengidentifikasikan data yang akan disimpan, diolah dan diubah untuk mendukung aktifitas bisnis suatu organisasi [1].

\section{Black-box testing}

Pengujian kotak hitam (black-box testing) dirancang untuk memvalidasi persyaratan fungsional tanpa perlu mengetahui kerja interna dari seebuah program. Teknik pengujian black box testing berfokus pada informasi dari perangkat lunak, menghasilkan test case dengan cara mempartisi masukan dan keluaran dari sebuah program dengan cara mencakup pengujian yang menyeluruh[10].

Metode penelitian itu merupakan cara ilmiah agar bisa memperoleh dan bisa mengumpulkan data-data dengan fungsi dan tujuan tertentu. Ada beberapa hal yang perlu untuk diketahui dan dipahami mengenai pengertian metode penelitian yakni cara ilmiah, datadata, fungsi dan juga tujuannya.
Pada Penelitian ini penulis menggunakan pendekatan kualitatif yaitu data yang tidak dapat dihitung namun berupa keterangan dan penjelasan. Data kualitatif diperoleh langsung dari narasumber dengan cara wawancara dan dokumentasi. Pada penelitian ini penulis ingin mengetahui keterkaitan Sistem Penerimaan dan Pengeluaran Kas yang telah berjalan dengan memenuhi kebutuhan sistem informasi pada SMP Widya Sakti.

\section{J. Sumber Data}

Sumber data yang digunakan oleh penulis dalam penelitian ini yaitu Data sekunder dalam penelitian ini, penulis menggunakan metode kepustakaan yang dilakukan dengan cara membaca referensi-referensi dari buku, jurnal, penelitian terdahulu dan artikel-artikel yang terkait dengan sistem informasi penerimaan dan pengeluaran kas

\section{K. Teknik Pengumpulan Data}

Untuk mempermudah laporan ini penulis menggunakan beberapa metode dalam proses pengumpulan data. Proses pengumpulan data dapat dibagi menjadi dua, yaitu :

1. Wawancara

Wawancara disini dilakukan dengan cara melakukan interaksi secara langsung (tatap muka) dengan narasumber petugas Bendahara SMP Widya Sakti ibu ida anindya di tempat. Dilakukan penelitian ini untuk mencari informasi yang berkaitan dengan Penerimaan dan Pengeluran Kas pada SMP Widya Sakti dan media apa saja yang digunakan dalam proses pencatatan keuangan.

2. Dokumentasi

Data yang didapat yaitu data yang berkaitan dengan penerimaan dan pengeluaran Kas pada SMP Widya Sakti. seperti kartu pembayaran Sumbangan Pembinaan dan Pendidikan (SPP), Laporan pembayaran SPP siswa pada buku harian, laporan pemungutan SPP bulanan SMP Widya Sakti, Buku Kas, laporan nota pengeluaran, Buku Kas Umum, Laporan Rancangan Kegiatan dan Anggaran Sekolah (RKAS), dan laporan pertanggungjawaban. Untuk lebih jelasnya dapat dilihat pada lampiran-lampiran.

\section{Alat dan Bahan}

Adapun Alat dan Bahan yang digunakan untuk menujuang kelancaran dalam penelitian ini adalah sebagai berikut :

1. Perangkat Keras Komputer (Hardware)

Processor

: Intel 2 Core N3350, Up to

$\begin{array}{ll}\text { Memory RAM } & : 2 \mathrm{~GB} \\ \text { Harddisk } & : 500 \mathrm{~GB}\end{array}$

2. Perangkat Lunak (Software)

Sistem Operasi : Windows 10

Aplikasi : Notepad++

Bahasa Pemograman : PHP

Basis Data : MySQL

Browser Internet $\quad$ : Chrome, Mozilla Firefox 


\section{Alur Penelitian}

Alur penelitian dalam penulisan ini menjelaskan mengenai tahapan peneliatian untuk merancang sistem informasi berbasis web. Maka dapat dirumuskan sebagai berikut :

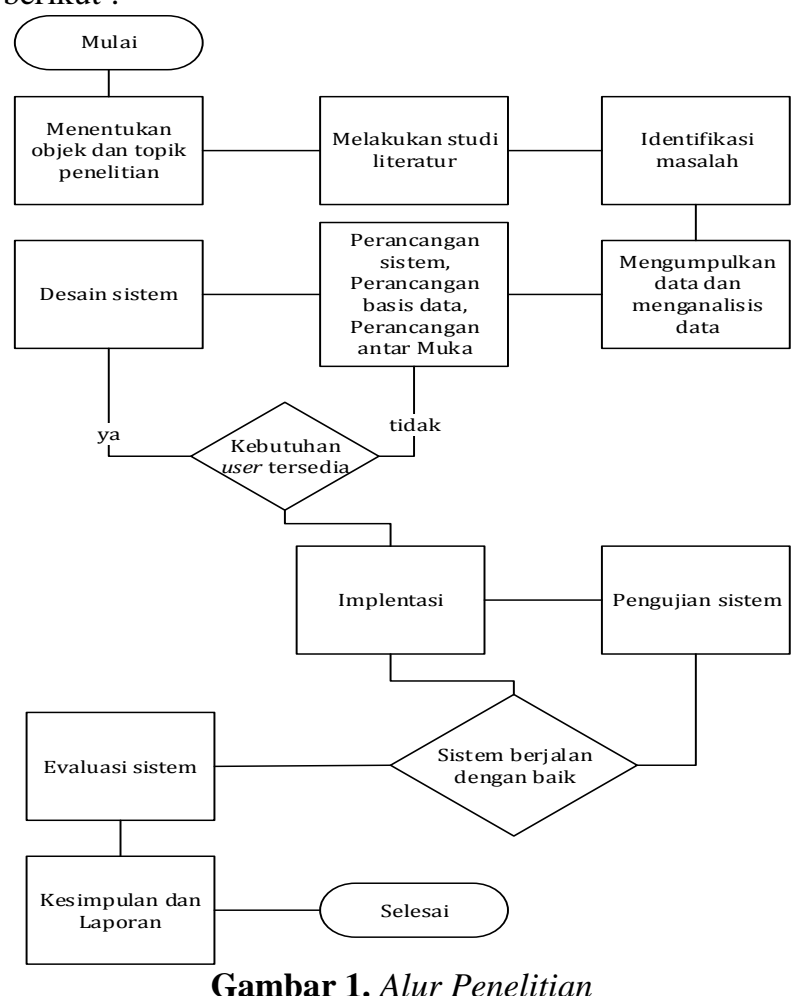

\section{N. Analisis Sistem}

Analisis sistem dilakukan untuk mengumpulkan data yang dibutuhkan dalam penelitian dalam pembuatan sistem ini, dimana tahapan ini juga bertujuan untuk memperoleh informasi mengenai harapan pengguna system yang akan dibangun. Sistem yang dibangun nantinya diharapkan dapat membantu pengguna dalam melakukan penerimaan pembayaran dan pengeluaran kas dimana sistem ini dapat membantu Tata Usaha (TU) dan bendahara dalam mencatat dan membuat laporan penerimaan dan pengeluaran Kas yang meliputi pencatatan pembayaran Sumbangan Pembinaan dan Pendidikan (SPP), data siswa, data kelas, jumlah pembayaran, bulan pembayaran, laporan penerimaan kas, laporan pembelian perlengkapan sekolah, laporan pengeluaran dan laporan pertanggung di SMP Widya Sakti.

\section{O. Analisis Kebutuhan Fungsional sistem}

Adapun kebutuhan fungsional sistem yang dibuat ini adalah :

1. Sistem hanya dapat memberikan hak akses kepada bagian Tata Usaha (TU) dan bendahara.

2. Sistem dapat membantu bagian Tata Usaha (TU) dalam mencatat penerimaan pembayaran Sumbangan Pembinaan dan Pendidikan (SPP).

3. Sistem dapat membantu bagian Tata Usaha (TU) dalam membuat laporan penerimaan pembayaran Sumbangan Pembinaan dan Pendidikan (SPP).
4. Sistem dapat membantu bagian bendahara dalam mencatat pengeluaran kas.

5. Sistem dapat membantu bagian bendahara dalam membuat laporan pengeluaran.

6. Sistem dapat membatu bagian bendahara dalam membuat laporan pertanggungjawaban.

\section{P. Analisis Kebutuhan non Fungsional Sistem}

Adapun kebutuhan non fungsional dari sitem yang dibuat ini adalah :

1. Dapat digunakan pada aplikasi google chrome, mozilla firefox dll.

2. Dapat diakses oleh computer pc.

3. Dapat menggunakan printer dalam mencetak file-file laporan

\section{Q. Rancangan Penelitian}

1. Sistem yang Sedang Berjalan

Tahapan ini merupakan gambaran umum sistem yang sedang berjalan di SMP Widya Sakti Denpasar. Menganalisis suatu sistem yang sedang berjalan merupakan salah satu tahap untuk manganalisis suatu sistem akankah sesuai dengan tujuan utama sistem itu sendiri yaitu mempermudah user. Berikut merupakan gambaran sistem informasi penerimaan dan pengeluaran kas yang sedang berjalan secara umum pada SMP Widya Sakti.

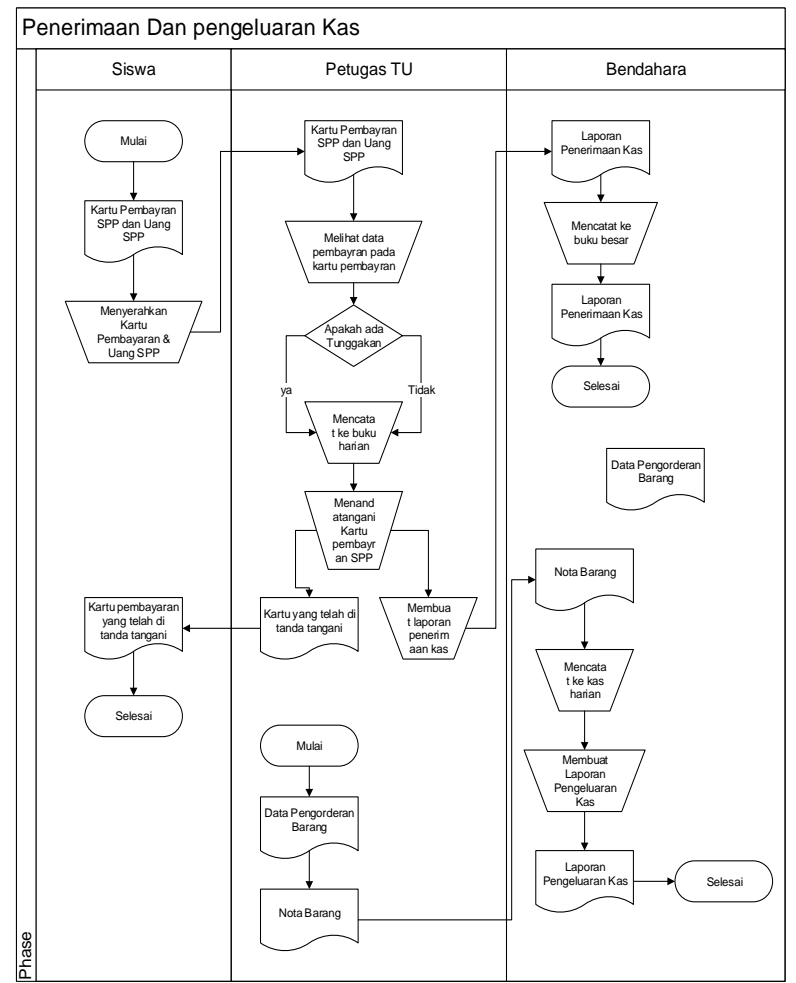

Gambar 2. Sistem yang sedang berjalan

\section{Diagram Konteks}

Diagram Konteks dibuat untuk menggambarkan proses pendokumentasian suatu sistem yang akan di buat untuk Memperlihatkan ruang lingkup dan keterbatasan dari sistem termasuk sistem lain yang berhubungan dengannya. 


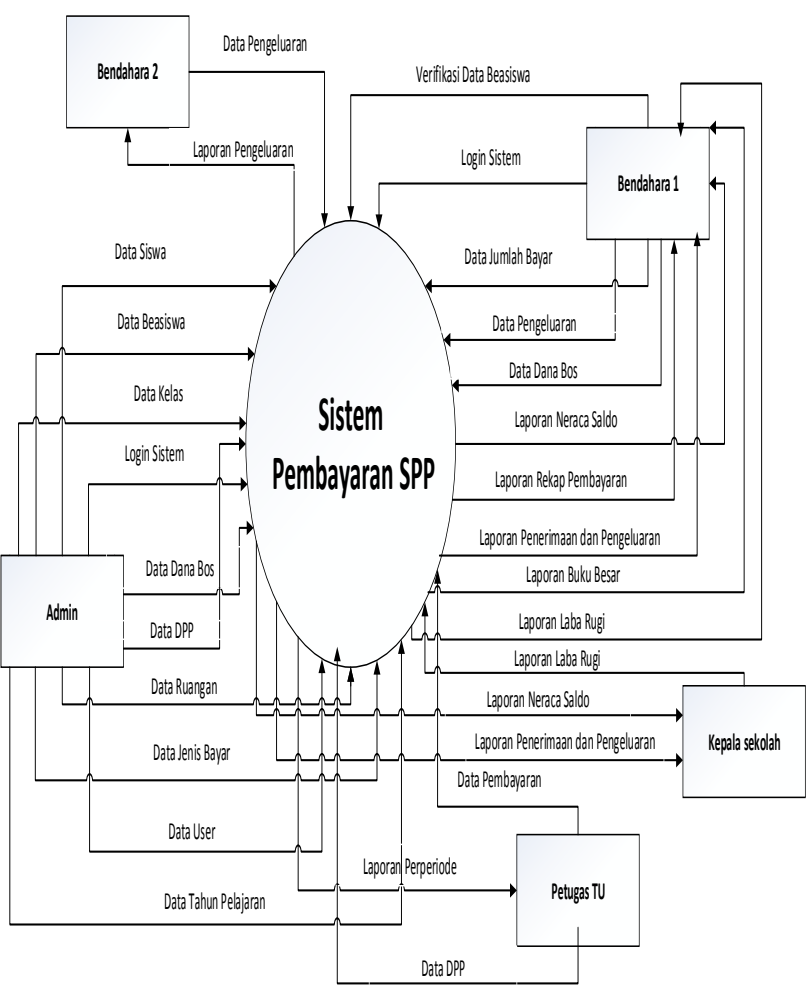

Gambar 3. Diagram konteks

\section{Diagram Level 0}

Berikut merupakan DFD dari sistem penerimaan kas dan pengeluaran kas yang diusulkan yang dibuat untuk mepermudah layanan penerimaan kas dan pembuatan laporan dari perimaan dan pengeluaran kas.

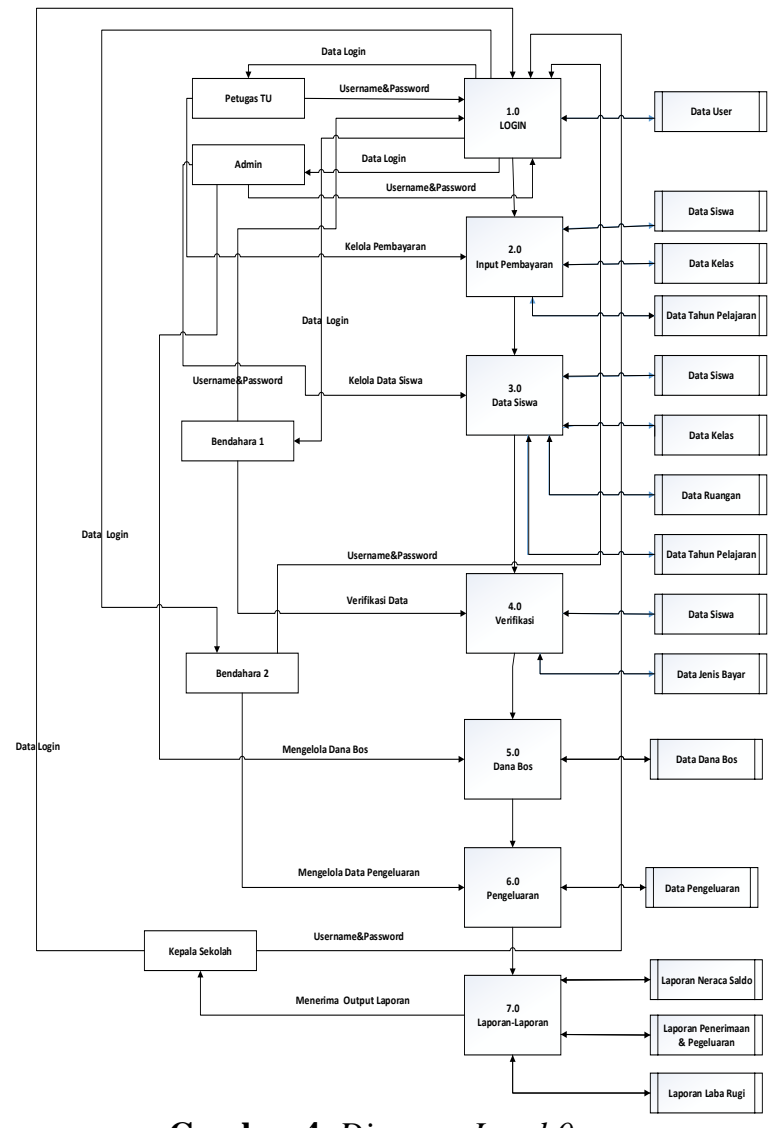

Gambar 4. Diagram Level 0

\section{R. Perancangan ERD}

Berikut adalah ERD dari sistem penerimaan dan pengeluaran kas yang diusulkan untuk dengan upaya mentrukturksn database yang akan di buat sehingga memberikan data base yang terstruktur dalam penggunaannya.

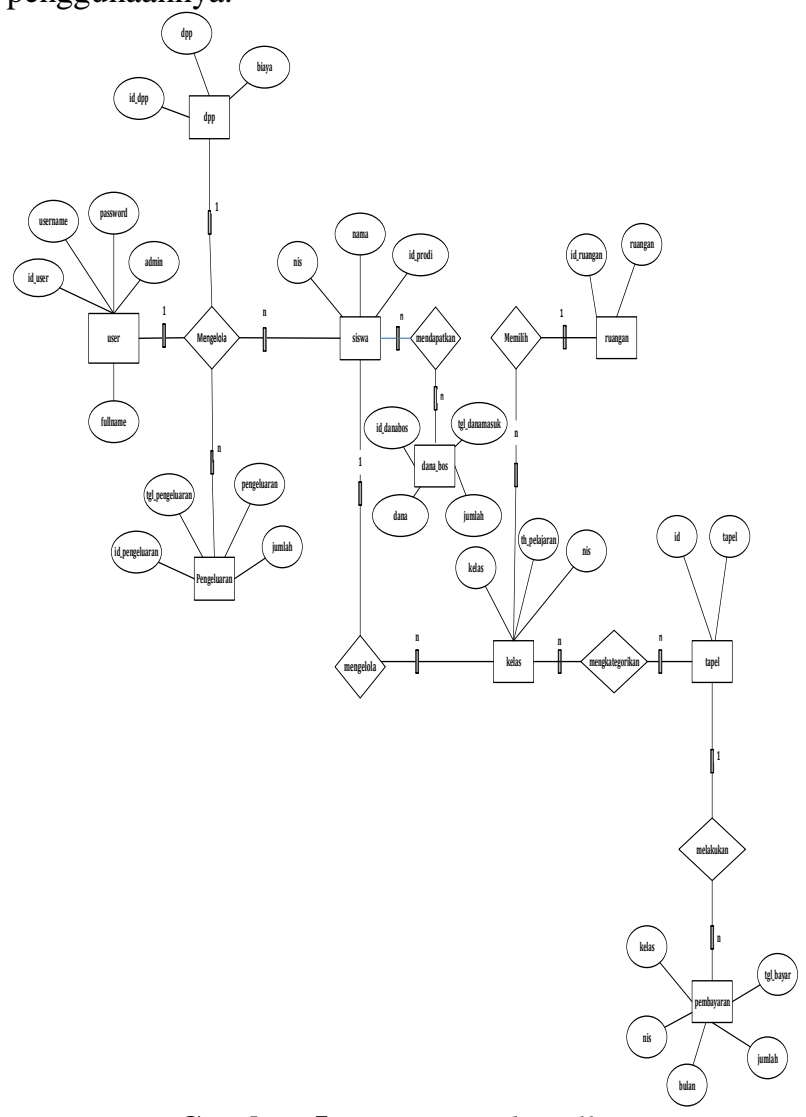

Gambar 5. ERD yang diusulkan

\section{S. Implementasi Sistem}

Pada bagian ini, penulis akan menampilkan hasil implentasi dari sistem yang buat yaitu sistem penerimaan dan pengeluaran kas berbasis WEB.

1. Halaman Login

\section{n SISTEM INFORMASI PEMBAYARAN SPP A}

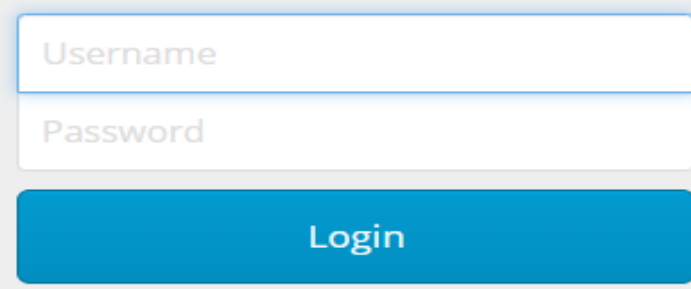

Gambar 6. Halaman Login

Pada halaman login, user harus memasukkan username dan password yang sudah diberikan oleh admin untuk dapat masuk ke halaman utama. 


\section{Halaman Utama}

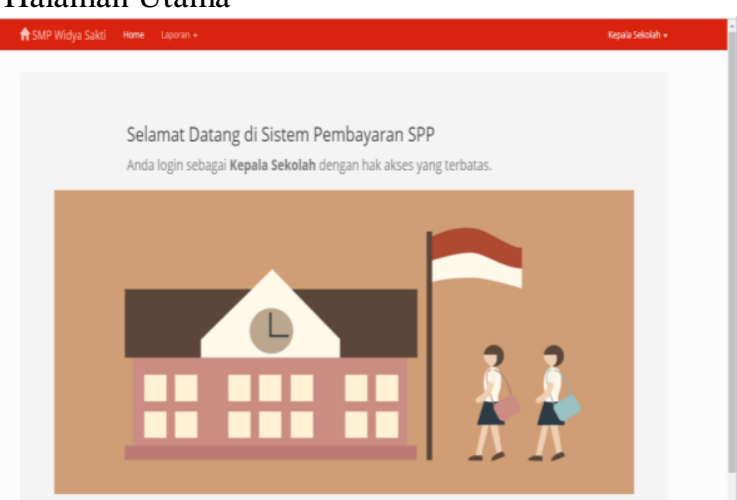

Gambar 7. Halaman Utama

Pada halaman utama terdapat beberapa menu pilihan yang dapat diakses oleh user.

\section{Halaman Tahun Ajaran}

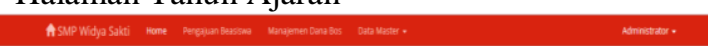

$$
\begin{aligned}
& \text { Konfigurasi Tahun Pelajaran }
\end{aligned}
$$

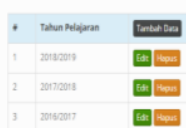

Gambar 8. Halaman Tahun Ajaran

Pada halaman ini, user dapat melihat tahun ajaran yang sudah terinput dan bisa menambahkan tahun ajaran dengan menambah data dana menginputkan tahun ajaran sesuai keinginan maka setelah disimpan akan terihat hasilnya seperti ini.

\section{Halaman Daftar Ruangan}
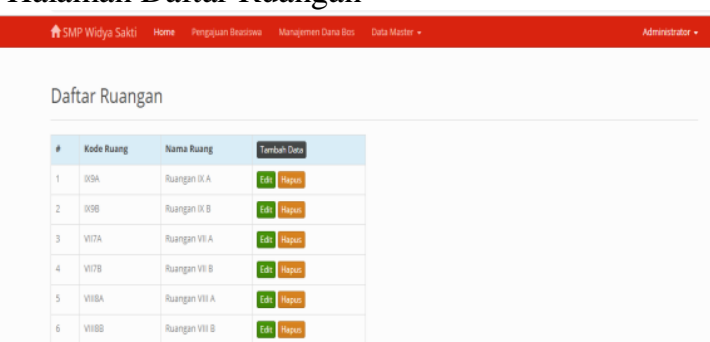

Gambar 9. Halaman Daftar Ruang

Pada halaman ini, user dapat menginput, menghapus dan mengedit data ruangan yang ada pada sekolah. Untuk menginput ruangan, user harus menabahakan data dan menginputkan ruangan yang tersedia.

\section{Halaman Daftar Kelas}

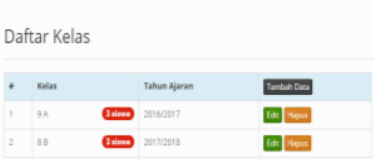

Gambar 10. Halaman Daftar Kelas
Pada halaman ini, user dapat menabah data kelas dan menambahkan data siswa pada kelas tersebut sehingga nanti akan terlihat jumlah murid yang ada pada kelas tersebut seperti gambar diatas.

\section{Halaman Data Siswa}

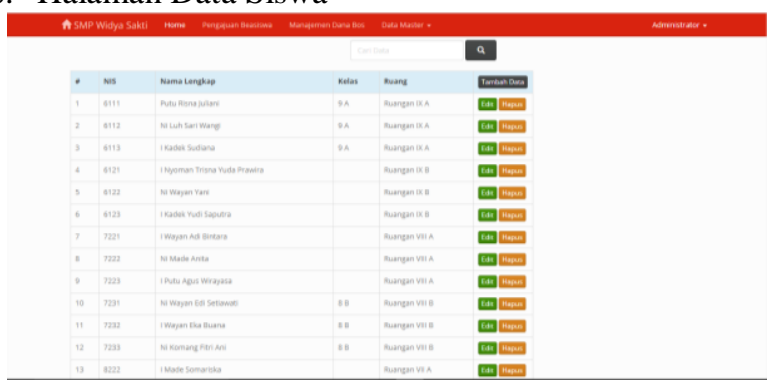

Gambar 11. Halaman Data Siswa

Pada halaman data siswa, user dapat menembahkan, mengedit dan mengahaspus data siswa dan hasilnya akan terlihat bahawa siswa tersebut sudah masuk ke kelas tersebut dan menempati ruang tersebut seperti dambar diatas.

\section{Halaman Penerimaan Dana Bos}

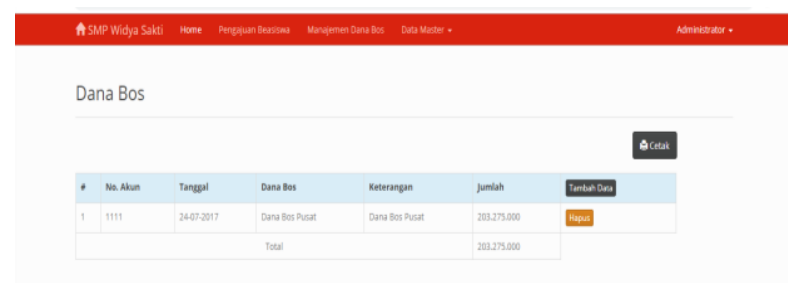

Gambar 12. Halaman Penerimaan Dana Bos

Pada halaman penerimaan dana bos, user dapat menginputkan data siswa yang mendapatkan dana yang diberikan pemerintah kepada SMP Widya Sakti sesuai dengan kwitansi yang tanda tangani oleh kepala sekolah. Kesalahan penginputan dana bos hanya dapat di edit oleh bagian bendhara 1 saja, untuk menghindari pemalsuan data.

8. Halaman Pengajuan Beasiswa
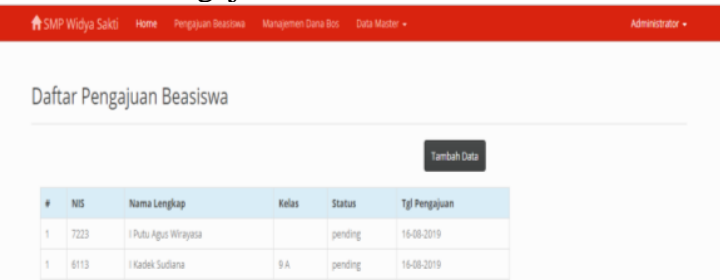

Gambar 13. Halaman Pengajuan Beasiswa

Pada halaman pengajuan beasiswa yang lakukan oleh bagian admin dimana data yang siswa yang diinput beradasarkan surat yang sudah ditanda tangani oleh kepala sekolah utuk menapatakan beasiswa karena siwa tersebut berprestasi. Jika admin salah menginputkan data maka bagian admin harus konfirmasi terlebih dahulu kepada bagian bendahara untuk melakukan pengeditan yang dilakukan oleh bagian bendahara. 


\section{Halaman Pembayaran}

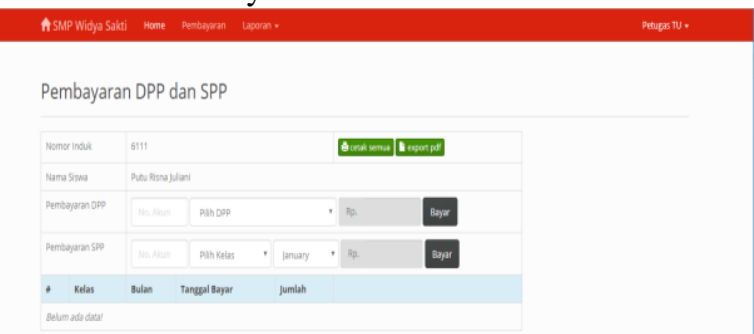

Gambar 14. Halaman Pembayaran

Pada halaman pembayaran ini, bagian penerimaan wajib menginputkan no akun yang sudah ada dalam perusahaan dan memilih jenis pembayaran setelah selesai pilih bayar maka data pembayaran siswa akan terlihat pada bagian bawah.

10. Halaman Rekapan Pembayaran
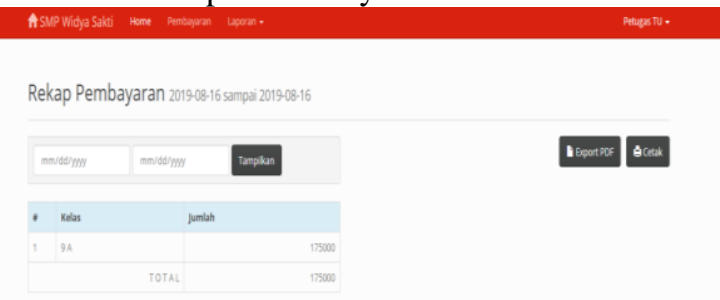

Gambar 15. Halaman Rekapan Pembayran

Pada halaman ini, bagian penerimaan bias melihat rekapan pembayaran yang telah terinput seperti gambar diatas.

\section{Halaman Pengeluaran}
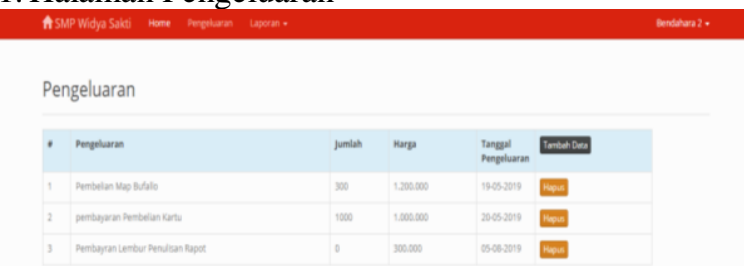

Gambar 16. Halaman Pengeluaran

Pada halaman pengeluaran user dapat menambah data pengeluaran tetap tidak dapat mengedit data pengeluaran, jika user ingin mengedit data pengeluaran makan user harus konfirmasi ke bagaian bendahara untuk melakukan pengeditan.

12. Halaman Laporan Pengeluaran

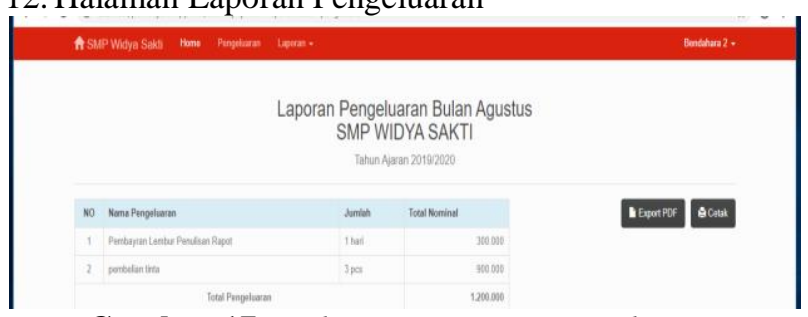

Gambar 17. Halaman Laporan Pengeluaran
Pada halaman laporan pengeluaran user dapat melihat hasil dari data pengeluaran yang telah diinput pada bulan tersebut.

\section{Halaman Daftar pengajuan Beasiswa}

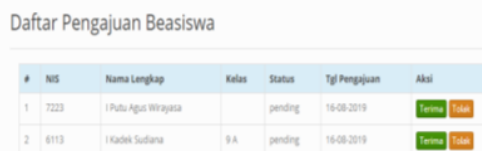

Gambar 18. Halaman Daftar Pengajuan Beasiswa

Halaman pengajuan beasiswa hanya dapat dibenarkan oleh bendahara 1 dimana jika data sudah diterima dan disetujui oleh bendahara 1 makan secara otomatis nominal pembayaran siswa tidak akan muncul.

14. Laporan Penerimaan dan Pengeluaran Kas

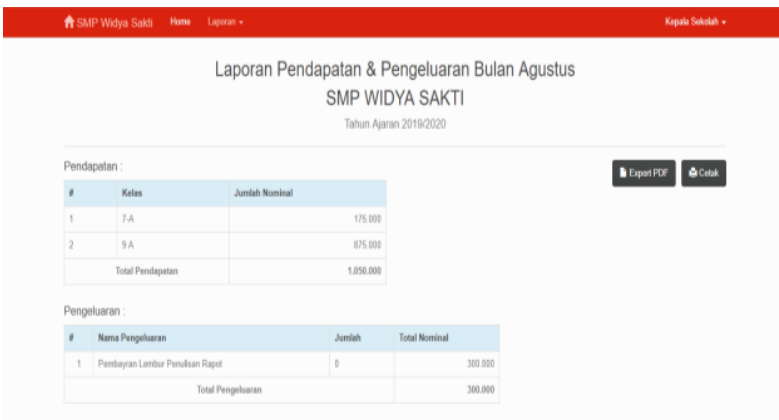

Gambar 19. Halaman Laporan Penerimaan dan Pengeluaran Kas

Pada halaman penerimaan dan penegluaran kas, user dapat melihat data penerimaan dan pengeluaran yang telah di inputkan.

\section{Laporan Buku Besar}

\section{Laporan Buku Besar
SMP WDYA SAKTT}

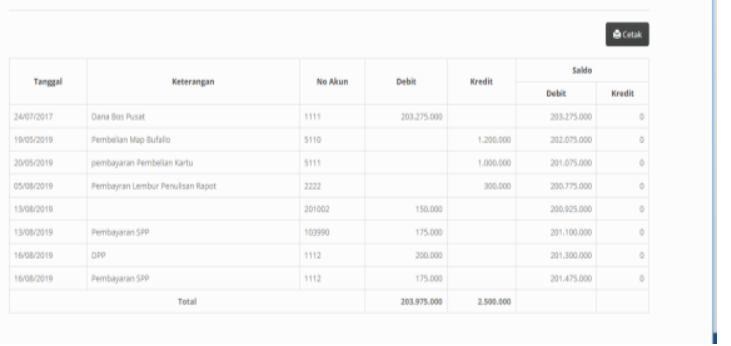

Gambar 20. Laporan Buku Besar

Pada laporan buku besar, akan terlihat catatan keuangan yang telah terjadi sesuai dengan data yang telah diinputkan. 


\section{Laporan Neraca Saldo}

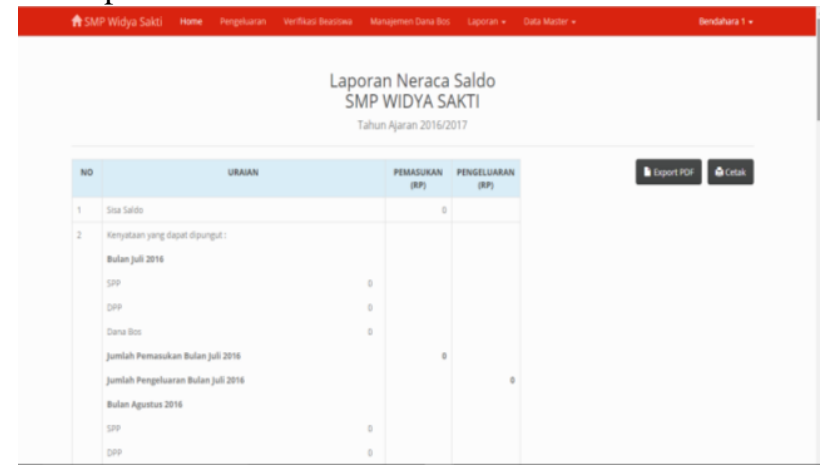

Gambar 21. Laporan Neraca Saldo

Pada laporan neraca saldo, data posisi keuangan instansi akan telihat secara nyata.

18. Laporan Laba Rugi

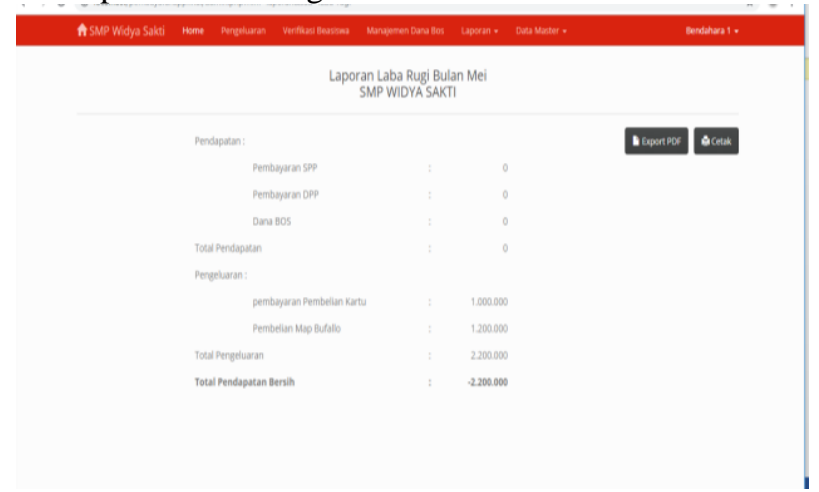

Gambar 22. Laporan Laba Rugi

Pada laporan laba rugi posisi kuangan suatu instansi akan terlihat apakah laba atau malah sebaliknya.

\section{Kesimpulan}

Adapun kesimpulan yang di dapatkan dalam uraian pembahasa di atas alah sebagai berikut :

Pengembangan Sistem Informasi Penerimaan Kas berbasis Web (Studi Kasus Pada SMP Widya Sakti) yang pada awalnya menggunakan ms.excel sekarang di kembangkan ke balam bentuk alplikasi website dengan menggunakan bahasa pemograman PHP dan Mysql sebagai databasenya yang membantu mudahkan transaksi penerimaan dan pengeluaran kas sehingga menghasilkan laporan yang diinginkan.

\section{Daftar Pustaka}

[1] J. Malik, "Sistem Informasi Pengelolaan dan Laporan Keuangan Dana BOS Berbasis Multi User di MTs Sudirman Jimbaran," J. Mhs. STEKOM Semarang, vol. 1, no. 1, 2014

[2] R. Daud and V. M. Windana, "Pengembangan Sistem Informasi Akuntansi Penjualan Dan Penerimaan Kas Berbasis Komputer Pada Perusahaan Kecil (Studi Kasus Pada Pt. Trust Technology)," Manaj. dan Bisnis, vol. 12, pp. 17-28, 2014.

[3] R. Hermawan, A. Hidayat, and V. G. Utomo, "Sistem Informasi Penjadwalan Kegiatan Belajar Mengajar
Berbasis Web," Indones. J. Softw. Eng. Sist., vol. 2, no. 1, pp. 31-38, 2016.

[4] F. A. Fairer-Wessels, "Information management education: towards a holistic perspective," South African J. Libr. Inf. Sci., vol. 65, no. 2, 2014.

[5] P. Sutopo, D. Cahyadi, and Z. Arifin, "Sistem Informasi Eksekutif Sebaran Penjualan Kendaraan Bermotor Roda 2 Di Kalimantan Timur Berbasis Web," J. Inform. Mulawarman, vol. 11, no. 1, p. 23, 2016.

[6] R. I. YUSTITIA, “Artikel Skripsi Universitas Nusantara PGRI Kediri," Implementasi Sms Getew. Untuk Layanan Inf. Absensi Siwa, vol. 01, no. 11, pp. 1-16, 2015.

[7] Sulfiati, A. Samsu, and Andi Lukman, "Akuntabilitas Pengelolaan Dana Bantuan Operasional Sekolah (BOS) dalam Penyelenggaraan Pendidikan di Kabupaten Sinjai," Ilmu Pemerintah., vol. 3, pp. 113-122, 2010.

[8] P. Pt, S. Galesong, and P. Cabang, "Analisis Sistem Pengendalian Intern Penerimaan Dan Pengeluaran Kas Pada Pt. Sinar Galesong Prima Cabang Manado," Anal. Sist. Pengendali. Intern Penerimaan Dan Pengeluaran Kas, vol. 1, no. 4, pp. 1007-1015, 2013.

[9] P. Wijaya, "Pengertian CD(Context Diagram) dan DFD (Data Flow Diagram) dan Simbolnya." 2012.

[10] "Sistem Informasi Penjadwalan Dokter Berbassis Web Dengan Menggunakan Framework Codeigniter (Studi Kasus: Rumah Sakit Yukum Medical Centre)," J. Teknoinfo, vol. 11, no. 2, pp. 30-37, 2017.

[11] A. P. Arum and M. A. Nugroho, "Perancangan Sistem Informasi Akuntansi Penerimaan Kas Berbasis Web Pada Batik Pramanca," J. Nominal, Barom. Ris. Akunt. dan Manaj., vol. 6, no. 1, 2017.

[12] E. Muslimah, "Perancangan Sistem Informasi Manajemen Kas Berbasis Web Studi Kasus : RS dr . Etty Asharto Batu," J. Ilmu Komput. dan Teknol. Inf., vol. 10, no. 1, pp. 21-25, 2018. 